\title{
Abundance, distribution and potential activity of methane oxidizing bacteria in permafrost soils from the Lena Delta, Siberia
}

\author{
Susanne Liebner* and Dirk Wagner \\ Alfred Wegener Institute for Polar and Marine Research, \\ Research Department Potsdam, Telegrafenberg A43, \\ 14473 Potsdam, Germany.
}

\section{Summary}

The methane oxidation potential of active layer profiles of permafrost soils from the Lena Delta, Siberia, was studied with regard to its respond to temperature, and abundance and distribution of type $I$ and type II methanotrophs. Our results indicate vertical shifts within the optimal methane oxidation temperature and within the distribution of type I and type II methanotrophs. In the upper active layer, maximum methane oxidation potentials were detected at $21^{\circ} \mathrm{C}$. Deep active layer zones that are constantly exposed to temperatures below $2^{\circ} \mathrm{C}$ showed a maximum potential to oxidize methane at $4^{\circ} \mathrm{C}$. Our results indicate a dominance of psychrophilic methanotrophs close to the permafrost table. Type I methanotrophs dominated throughout the active layer profiles but their number strongly fluctuated with depth. In contrast, type II methanotrophs were constantly abundant through the whole active layer and displaced type I methanotrophs close to the permafrost table. No correlation between in situ temperatures and the distribution of type I and type II methanotrophs was found. However, the distribution of type I and type II methanotrophs correlated significantly with in situ methane concentrations. Beside vertical fluctuations, the abundance of methane oxidizers also fluctuated according to different geomorphic units. Similar methanotroph cell counts were detected in samples of a flood plain and a polygon rim, whereas cell counts in samples of a polygon centre were up to 100 times lower.

Received 3 May, 2006; accepted 11 July, 2006. *For correspondence. E-mail sliebner@awi-potsdam.de; Tel. (+49) 331288 2200; Fax (+49) 3312882137.

\section{Introduction}

The Arctic is of major interest in the context of global climatic change for two reasons. First, one-third of the global carbon pool is stored in northern latitudes (Post et al., 1982), mainly in huge layers of frozen ground, termed permafrost, which cover around $24 \%$ of the exposed land area of the Northern Hemisphere (Zhang et al., 1999). Second, the Arctic is observed to warm more rapidly and to a greater extent than the rest of the earth surface (IPCC, 2001). Serreze and colleagues (2000) refer to evidence of increased plant growth and northward migration of the tree line and conclude that permafrost has warmed in Alaska and Russia.

Northern wetlands such as the Lena Delta in north-east Siberia are significant natural sources of methane (Friborg et al., 2003; Smith et al., 2004; Corradi et al., 2005). As a consequence of the harsh winter climate, decomposition processes in northern wetlands are inhibited leading to an accumulation of organic matter. The organic matter is partly decomposed under watersaturated, anaerobic conditions during the short summer period. The terminal step in the anaerobic decomposition of organic matter is the microbial formation of methane (methanogenesis). Several studies estimated the methane source strength of northern wetlands, including tundra, to range from 17 to $42 \mathrm{Tg} \mathrm{CH}_{4}$ year ${ }^{-1}$ (Whalen and Reeburgh, 1992; Cao et al., 1996; Joabsson and Christensen, 2001; Wagner et al., 2003). This corresponds to about $25 \%$ of the methane release from natural sources (Fung et al., 1991).

Global warming could thaw $25 \%$ of the permafrost area by 2100 (Anisimov et al., 1999), exposing huge amounts of currently fixed organic carbon to aerobic as well as anaerobic decomposition processes. Also, higher temperatures are likely to reinforce methanogenesis and therefore increase the methane source strength of Arctic wetlands (Wuebbles and Hayhoe, 2002). Additional methane would have a positive feedback on the atmospheric warming process because methane is both on a mass and a molecule level 23 times more effective as a greenhouse gas than $\mathrm{CO}_{2}$ (IPCC, 2001).

The biological oxidation of methane by methane oxidizing (methanotrophic) bacteria, which belong to the 
$\alpha$ - (type II methanotrophs) and $\gamma$ - (type I methanotrophs) Proteobacteria, is the major sink for methane in terrestrial habitats. Between $43 \%$ and $90 \%$ of the methane produced in the soil is oxidized before reaching the atmosphere (Roslev and King, 1996; Le Mer and Roger, 2001). Hence, it is crucial to investigate methanotrophic communities and their response to global change in particular in climatic sensitive regions like the Lena Delta.

Our study determines abundance and distribution of methanotrophic bacteria within morphologically characteristic sites on Samoylov Island. Samoylov Island is located in the central part of the Lena Delta and is representative for the polygonal tundra, which is typical for the patterned ground of permafrost. We will also give insights into how the extreme environmental conditions of Siberian permafrost influence potential methane oxidation rates. Particularly, the temperature response of potential methane oxidation rates in soils from the Lena Delta was investigated as temperature is the most extreme parameter in permafrost soils and it is known that low temperatures induce processes of microbial adaptation and specialization (Georlette et al., 2004).

\section{Results}

\section{Soil characteristics}

The microrelief of the polygonal tundra, which results from annual freezing and thawing processes, determines steep environmental gradients in particular within the active layer (seasonally thawed layer) of permafrost. Three sites were investigated in this study: a polygon rim, a polygon centre and a flood plain soil. Temperature and methane gradients through the active layer profiles of the three sampling sites were determined during the sampling periods and are shown in Fig. 1. In the uppermost $5 \mathrm{~cm}$ mean temperature values reached up to $5-12^{\circ} \mathrm{C}$ in the polygon rim and centre, and $18^{\circ} \mathrm{C}$ in the flood plain. In all profiles, temperatures decreased rapidly to almost $0^{\circ} \mathrm{C}$ in $25-40 \mathrm{~cm}$ depth close to the permafrost table. Temperatures in the uppermost soil layers fluctuated at greater amplitude than in layers close to the permafrost table, where they remained constantly around $0^{\circ} \mathrm{C}$.

The methane concentration profiles of the polygon rim and the flood plain showed a steep gradient between the upper and the deeper active layer. Within both profiles, methane concentrations increased rapidly from around $50 \mathrm{nmol} \mathrm{g}^{-1}$ (dw) in the uppermost $18 \mathrm{~cm}$ to 140 $180 \mathrm{nmol} \mathrm{g}^{-1}$ (dw) close to the permafrost table. Compared with the flood plain and the polygon rim, the methane concentrations in the polygon centre were up to 10 times higher and did not show a vertical gradient.

Additional soil properties of the three sites are summarized in Table 1. The organic carbon content did not

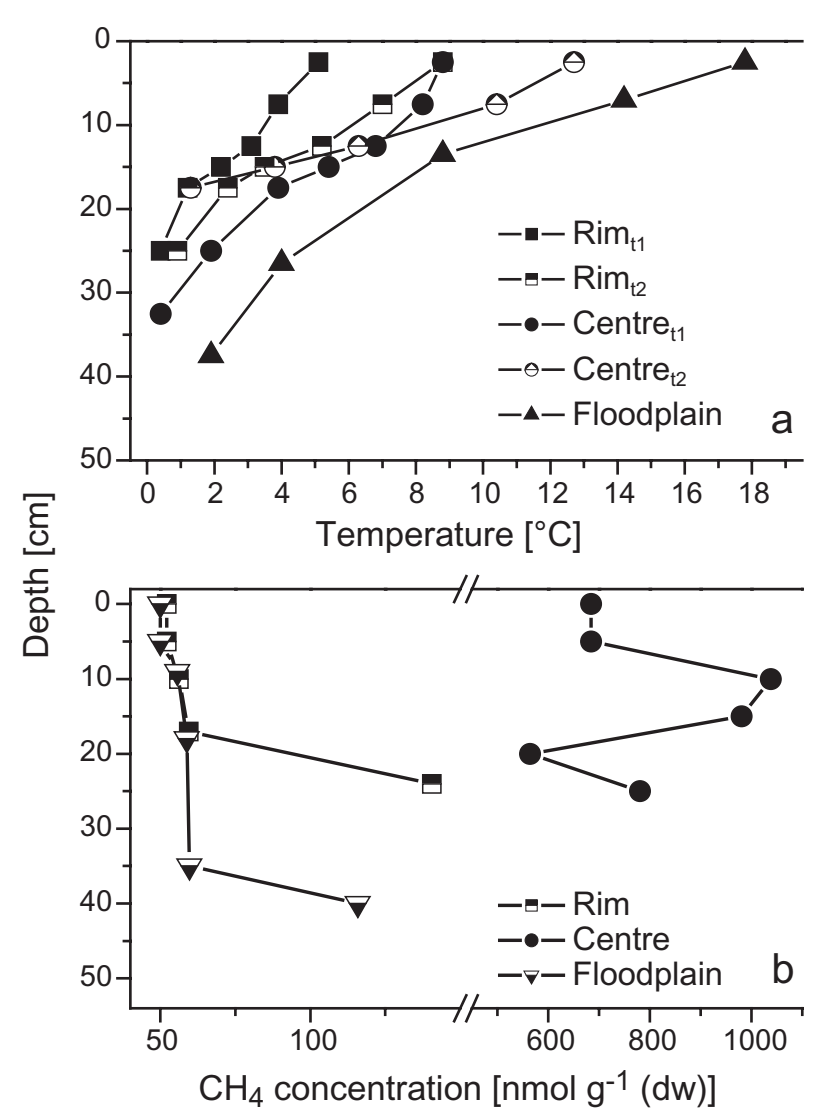

Fig. 1. Vertical profiles of (a) in situ temperatures and (b) in situ methane concentrations in the active layer of a polygon rim, a polygon centre and a flood plain soil on Samoylov Island, Lena Delta. Temperatures represent mean values $(n=3)$ measured around noon (11 AM to 1 PM) on 21st July (t1) and 2nd August 2005 (t2) (polygon rim and polygon centre) and on 22nd July 2002 (flood plain). Methane concentrations represent mean values $(n=3)$ of active layer cores sampled around noon on 22nd July 2005 (polygon rim and polygon centre) and on 22nd July 2002 (flood plain).

exceed $3.0 \%$ and $3.1 \%$, respectively, in the polygon rim and the flood plain but reached up to $16.1 \%$ in the polygon centre. In contrast to the polygon rim, which was dominated by sandy material, the flood plain mainly consisted of silty material. The grain size fraction of the polygon centre could not be determined due to its high content of organic soil matter.

\section{Cell numbers}

Total and methanotroph cell counts were determined for all sites. Additionally, cell counts of Bacteria were determined for the polygon rim and the polygon centre. All cell numbers are shown in Fig. 2. Cell counts of Bacteria and methanotrophs relative to total cell counts (TCC) are summarized in Table 2.

Within the upper active layer profiles $(0-10 \mathrm{~cm})$, TCC were highest in the polygon rim $\left[20.1 \times 10^{8}\right.$ cells g $\left.^{-1}(\mathrm{dw})\right]$. 
Table 1. Selected soil properties of a polygon rim, a polygon centre and a flood plain soil on Samoylov Island, Lena Delta.

\begin{tabular}{|c|c|c|c|c|c|c|}
\hline \multirow{2}{*}{$\begin{array}{l}\text { Depth } \\
(\mathrm{cm})\end{array}$} & \multirow{2}{*}{$\begin{array}{l}\mathrm{H}_{2} \mathrm{O} \text { content } \\
(\%)\end{array}$} & \multirow[b]{2}{*}{$\begin{array}{l}\mathrm{C}_{\text {org }} \\
(\%)\end{array}$} & \multirow{2}{*}{$\begin{array}{l}N \\
(\%)\end{array}$} & \multicolumn{3}{|c|}{ Grain size fraction (\%) } \\
\hline & & & & Clay & Silt & Sand \\
\hline \multicolumn{7}{|l|}{ Rim } \\
\hline $0-6$ & 26.2 & 3.0 & 0.2 & 2.4 & 10.6 & 87.0 \\
\hline $6-11$ & 15.7 & 2.1 & 0.1 & 2.3 & 9.1 & 88.5 \\
\hline $11-18$ & 24.1 & 2.3 & 0.1 & 1.7 & 17.5 & 80.7 \\
\hline $18-25$ & 24.8 & 2.0 & 0.1 & 10.0 & 45.7 & 44.3 \\
\hline $25-32$ & 25.2 & 1.2 & 0.0 & 3.0 & 11.1 & 85.9 \\
\hline $32-38$ & 16.6 & 2.8 & 0.1 & 0.5 & 21.5 & 78.1 \\
\hline \multicolumn{7}{|l|}{ Centre } \\
\hline $0-5$ & 85.7 & 15.5 & 0.7 & $-^{a}$ & $-^{a}$ & $Z^{a}$ \\
\hline $5-10$ & 77.3 & 15.1 & 0.4 & $-^{a}$ & $-^{\mathrm{a}}$ & $-^{\mathrm{a}}$ \\
\hline $10-15$ & 80.6 & 16.1 & 0.4 & $-^{\mathrm{a}}$ & $-^{a}$ & $-^{a}$ \\
\hline $15-20$ & 73.4 & 7.3 & 0.2 & $-^{a}$ & $-^{a}$ & $-^{a}$ \\
\hline $20-25$ & 58.9 & 2.2 & 0.2 & $-^{a}$ & $-^{\mathrm{a}}$ & $-^{a}$ \\
\hline $25-30$ & 68.5 & 4.7 & 0.2 & $-^{a}$ & $-^{a}$ & $-^{\mathrm{a}}$ \\
\hline \multicolumn{7}{|c|}{ Flood plain } \\
\hline $0-5$ & 30.1 & 3.1 & 0.4 & 11.1 & 64.8 & 24.2 \\
\hline $5-9$ & 31.9 & 1.1 & 0.2 & 20.2 & 61.4 & 18.4 \\
\hline $9-18$ & 28.3 & 2.2 & 0.3 & 18.3 & 63.5 & 18.2 \\
\hline $18-35$ & 35.4 & 2.8 & 0.4 & 20.2 & 62.7 & 17.1 \\
\hline $35-40$ & 32.4 & 2.4 & 0.3 & 20.4 & 55.6 & 24.0 \\
\hline $40-52$ & 31.8 & 1.7 & 0.2 & 17.6 & 67.7 & 14.7 \\
\hline
\end{tabular}

a. Was not determined due to the high content of organic soil matter.

Total cell counts were in the same range in the polygon centre and in the flood plain $\left[3.7 \times 10^{8}\right.$, respectively, $5.1 \times 10^{8}$ cells $\left.\mathrm{g}^{-1}(\mathrm{dw})\right]$. Close to the permafrost table, TCC were similar in all sites and ranged between

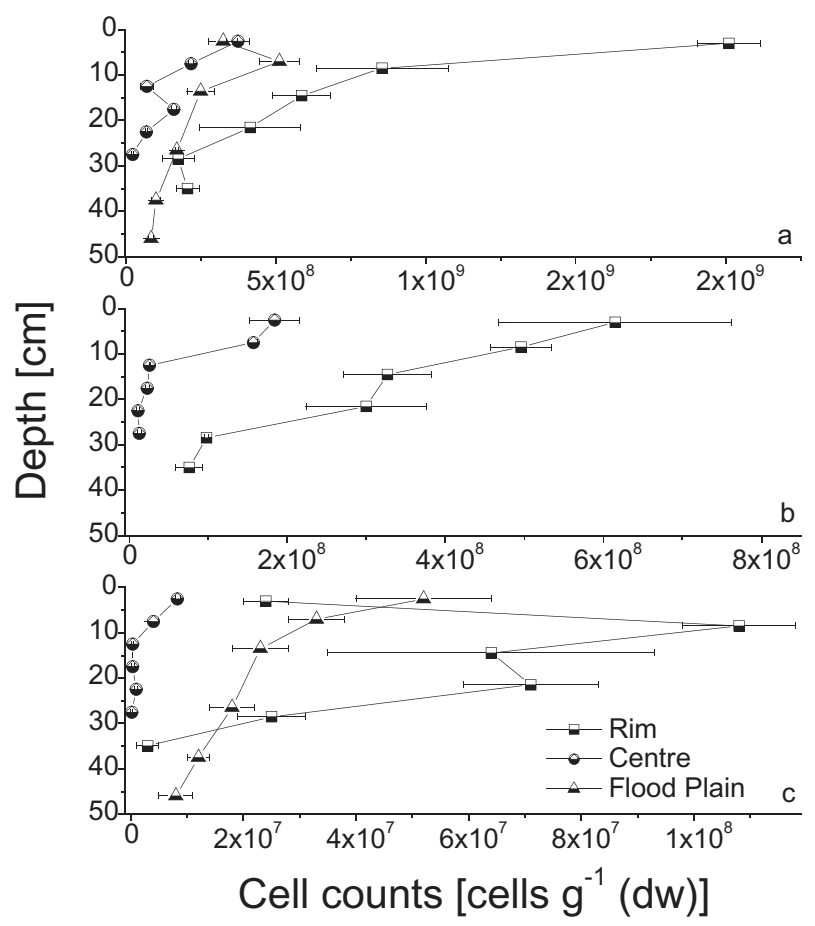

Fig. 2. (a) Total, (b) Bacteria and (c) methanotroph cell counts of a polygon rim, a polygon centre and a flood plain soil on Samoylov Island, Lena Delta.
$1.7 \times 10^{8}$ cells $\mathrm{g}^{-1}(\mathrm{dw})$ in the polygon rim and $0.2 \times 10^{8}$ cells $\mathrm{g}^{-1}(\mathrm{dw})$ in the polygon centre.

Cell numbers detected with probe EUB338, which identified members of the domain Bacteria, were 5-10 times

Table 2. Ratio of type I to type II methanotrophs and cell counts of Bacteria and methanotrophs relative to TCC of a polygon rim, a polygon centre and a flood plain soil on Samoylov Island, Lena Delta.

\begin{tabular}{|c|c|c|c|}
\hline \multirow{2}{*}{$\begin{array}{l}\text { Depth } \\
(\mathrm{cm})\end{array}$} & \multirow{2}{*}{$\begin{array}{l}\text { Ratio } \\
\text { Type I/Type II } \\
\text { MOB }^{a}(\%)\end{array}$} & \multicolumn{2}{|c|}{$\begin{array}{l}\text { Relative to TCC (\%) } \\
\quad(\text { mean } \pm \text { SD) }\end{array}$} \\
\hline & & Bacteria & $\mathrm{MOB}^{\mathrm{a}}$ \\
\hline \multicolumn{4}{|l|}{ Rim } \\
\hline $0-6$ & $56.9 / 43.1$ & $30.5 \pm 7.3$ & $1.2 \pm 0.2$ \\
\hline $6-11$ & $88.5 / 11.5$ & $58.1 \pm 4.5$ & $12.7 \pm 1.2$ \\
\hline $11-18$ & $60.3 / 39.7$ & $55.9 \pm 9.6$ & $11.0 \pm 5.0$ \\
\hline $18-25$ & $95.6 / 4.4$ & $72.4 \pm 18.5$ & $17.3 \pm 2.9$ \\
\hline $25-32$ & $50.0 / 50.0$ & $56.2 \pm 2.1$ & $14.6 \pm 3.5$ \\
\hline $32-38$ & $<$ d.l. $/ 100.0$ & $37.2 \pm 8.5$ & $1.7 \pm 1.1$ \\
\hline \multicolumn{4}{|l|}{ Centre } \\
\hline $0-5$ & n.d. & $49.3 \pm 8.6$ & $0.2 \pm 0.1$ \\
\hline $5-10$ & n.d. & $72.3 \pm 2.9$ & $1.9 \pm 0.8$ \\
\hline $10-15$ & n.d. & $38.5 \pm 1.4$ & $0.5 \pm 0.3$ \\
\hline $15-20$ & n.d. & $14.9 \pm 1.6$ & $0.2 \pm 0.1$ \\
\hline $20-25$ & n.d. & $16.2 \pm 3.7$ & $1.4 \pm 0.3$ \\
\hline $25-30$ & n.d. & $57.3 \pm 10.7$ & $0.7 \pm 0.5$ \\
\hline \multicolumn{4}{|c|}{ Flood plain } \\
\hline $0-5$ & $93.7 / 6.3$ & n.d. & $16.1 \pm 3.8$ \\
\hline $5-9$ & $69.5 / 30.5$ & n.d. & $6.4 \pm 1.1$ \\
\hline $9-18$ & $64.5 / 35.5$ & n.d. & $9.3 \pm 2.3$ \\
\hline $18-35$ & $84.9 / 15.1$ & n.d. & $10.8 \pm 2.6$ \\
\hline $35-40$ & $38.3 / 61.7$ & n.d. & $12.1 \pm 2.7$ \\
\hline $40-52$ & $25.8 / 74.2$ & n.d. & $9.5 \pm 4.7$ \\
\hline
\end{tabular}

a. Methane oxidizing bacteria.

n.d., not determined. 
higher in the polygon rim than in the polygon centre. They varied between $6.1 \times 10^{8}(0$ and $6 \mathrm{~cm})$ and $0.7 \times 10^{8}$ cells $\mathrm{g}^{-1}(\mathrm{dw})(32-38 \mathrm{~cm})$ in the polygon rim and between $1.8 \times 10^{8}(0$ and $5 \mathrm{~cm})$ and $0.1 \times 10^{8}$ cells g $^{-1}(\mathrm{dw})(25-$ $30 \mathrm{~cm}$ ) in the polygon centre. Hence, their contribution to TCC was $30.5-72.4 \%$ at the polygon rim and $14.9-72.3 \%$ at the polygon centre.

Methanotroph cell counts were highest in the polygon rim where they ranged between $1.0 \times 10^{8}(6$ and $11 \mathrm{~cm})$ and $3.0 \times 10^{6}$ cells g $^{-1}(\mathrm{dw})(32-38 \mathrm{~cm})$. Methanotroph cell counts in the polygon rim accounted for $1.7-17.3 \%$ to the TCC. Methanotroph cell counts of the polygon centre were two orders of magnitude lower than in the polygon rim and in the flood plain and accounted for only $0.2 \%$ to at most $1.9 \%$ to TCC. In the flood plain, cell counts of methanotrophs varied between $5.0 \times 10^{7}(0$ and $5 \mathrm{~cm})$ and $8.0 \times 10^{6}$ cells g $^{-1}(\mathrm{dw})(40-52 \mathrm{~cm})$ and accounted for $6.4-16.1 \%$ to TCC.

\section{Distribution of type I and type II methanotrophs}

The vertical distribution of type I and type II methanotrophs was determined for the polygon rim and the flood plain soil (Fig. 3). Within both profiles, type I methanotrophs dominated through the active layer but their abundance strongly fluctuated with depth. Type II methanotrophs were less abundant than type I methanotrophs and their cell numbers fluctuated less with depth. Type II methanotrophs displaced type I methanotrophs close to the permafrost table. The relative abundance of type I and type II to total methanotroph cells (Table 2) resulted in a significant sigmoidal correlation (Boltzmann model) with the methane concentrations in situ for both profiles (rim: $r^{2}=0.993, \chi^{2}=28.99, \quad n=6$; flood plain: $r^{2}=0.819$, $\chi^{2}=26.98, n=6$ ). A correlation between distribution of type I and type II methanotrophs and in situ temperatures could not be detected.

\section{Potential methane oxidation rates}

Incubation experiments (based on ${ }^{14} \mathrm{CH}_{4}$ ) were carried out at $0,4,12,21,28$ and $38^{\circ} \mathrm{C}$ with soil slurries of the polygon rim and the polygon centre. Another incubation experiment (based on the linear regression of $\mathrm{CH}_{4}$ in the headspace determined by gas chromatography) was carried out with soil slurries of the flood plain at $0,4,12$ and $21^{\circ} \mathrm{C}$.

The potential to oxidize methane at different incubation temperatures was similar in samples of the polygon rim and the flood plain soil. Maximum rates of around $50 \mathrm{nmol} \mathrm{g}^{-1}(\mathrm{dw})$ day $^{-1}$ were detected in samples of both sites. There was a clear shift of the temperature optimum from $21^{\circ} \mathrm{C}$ in upper active layer zones to $4^{\circ} \mathrm{C}$ in deeper active layer zones in both profiles (Fig. 4). In samples of

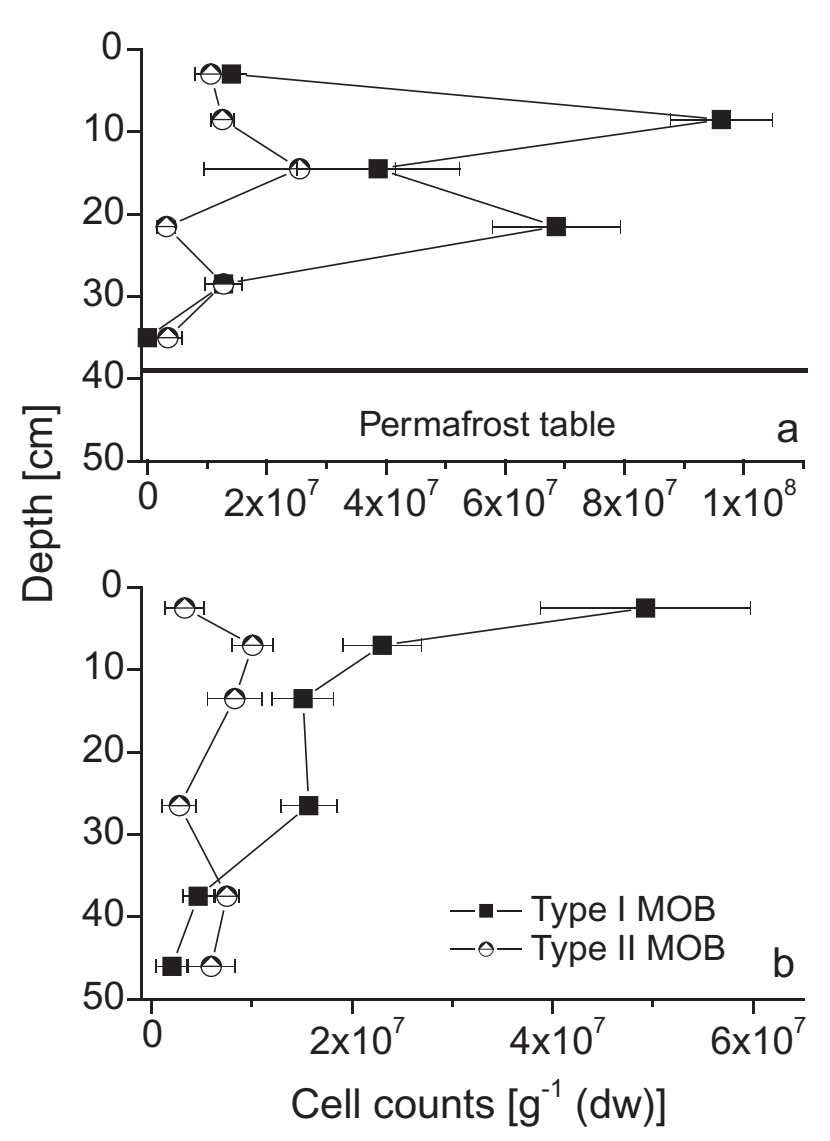

Fig. 3. Vertical distribution of type I and type II methanotrophic bacteria through the active layer of (a) a polygon rim and (b) a flood plain soil on Samoylov Island, Lena Delta.

the polygon rim and the flood plain, the potential methane oxidation rates per gram dry weight of deep soil layers at $4^{\circ} \mathrm{C}$ were similar to those of upper layers at $21^{\circ} \mathrm{C}$. Based on the cell counts determined by fluorescence in situ hybridization (FISH) and on the potential oxidation rates measured at various incubation temperatures, the potential methane oxidation rates per methanotroph cell and day were calculated. At $4^{\circ} \mathrm{C}$ the potential methane oxidation rates per methanotroph cell detected near the permafrost table exceeded cell activities in the other horizons by one order of magnitude (Fig. 4). Independently of the temperature, cell activities increased by $50-150 \%$ compared with upper soil layers at $25 \mathrm{~cm}$ in the polygon rim and at $40 \mathrm{~cm}$ in the flood plain. Lowest rates $\left[<23 \mathrm{nmol} \mathrm{g}^{-1}(\mathrm{dw}) \mathrm{d}^{-1}\right]$ through the active layer profiles were detected at $0^{\circ} \mathrm{C}$ at both sites and at $38^{\circ} \mathrm{C}$ in samples of the polygon rim (Fig. 4). Soil horizons with the highest abundance of methanotrophs did not show any temperature response (polygon rim: 6-11 cm and 18-25 cm; flood plain: $5-40 \mathrm{~cm}$ ). In these horizons the methane oxidation potential did not change significantly at the different incubation temperatures. The methane oxidizing potential through the entire active layer of the polygon centre was 


\section{$\mathrm{CH}_{4}$ oxidation rate $\left[\mathrm{nmol}\right.$ cell-1 $\left.\mathrm{d}^{-1}\right]$}
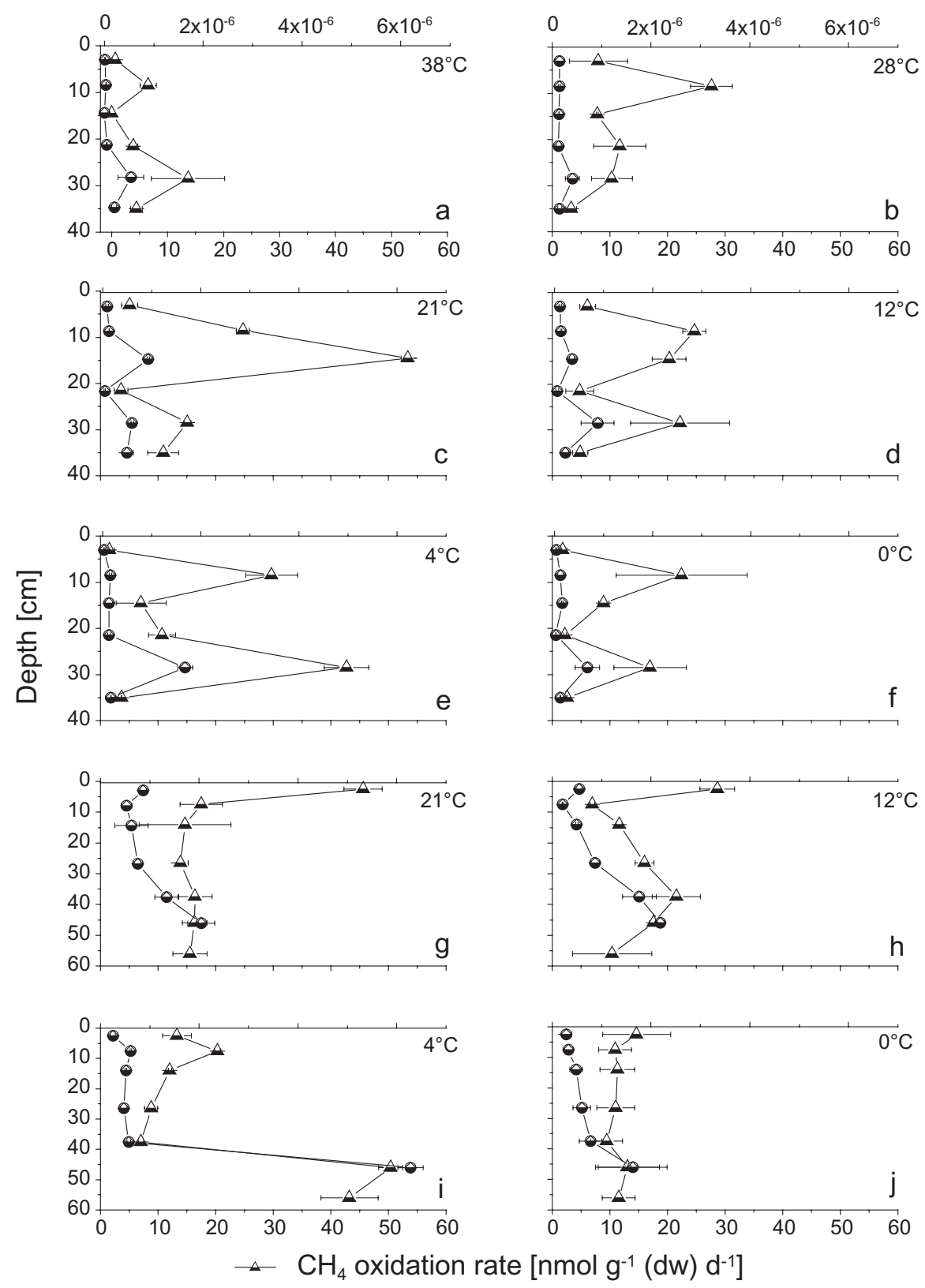

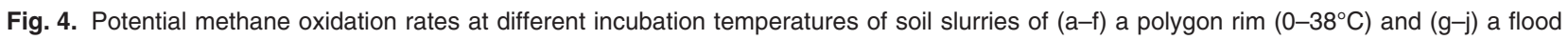
plain soil $\left(0-21^{\circ} \mathrm{C}\right)$ on Samoylov Island, Lena Delta.

about two orders of magnitude lower than in samples of the rim and the flood plain (data not shown).

\section{Discussion}

Soil ecosystems of the Siberian Arctic are characterized by small-scale variations both within the microrelief of the polygonal tundra and within vertical profiles of the active layer. Within the active layer, temperature is the most extreme environmental factor with a distinct gradient from the surface to the permafrost table.

At different sites examined in this study, the potential to oxidize methane of soil horizons close to the permafrost table was greatest at $4^{\circ} \mathrm{C}$. The methane oxidation potentials per methanotroph cell near the permafrost table was significantly higher compared with both the cell activities near the surface at the same temperature $\left(4^{\circ} \mathrm{C}\right)$ but also compared with cell activities in the same depth at different 
temperatures (Fig. 4). Hence, our results indicate that the methanotrophic community close to the permanently frozen ground is dominated by psychrophiles. In contrast, the methanotrophic community in upper soil layers, which shows a maximum oxidation potential at $21^{\circ} \mathrm{C}$, might be dominated by psychrotolerants or by a mixed community of mesophiles and psychrotolerants. We suggest that with increasing depth of the active layer the methanotrophic bacteria become more adapted to low temperatures. This is confirmed by higher amounts of unsaturated phospholipid fatty acids (PLFAs) accompanied by larger headgroups and increased amounts of short-chain fatty acids of bacteria in deeper compared with upper active layer zones of the polygon rim (K. Mangelsdorf and D. Wagner, pers. comm.). Also, Wagner and colleagues (2005) could show that the relative abundance of branched chain fatty acids, indicating an increased fluidity of prokaryotic cell membranes and by this an improved adaptation to low temperatures, significantly increases with active layer depth. It is known that cold adaptation comprises a complex pattern of different structural changes within the cell and that these structural changes are regulated on the genomic level (Cavicchioli, 2006). Therefore, it is rather unlikely that all methanotrophic species are equally competent to adapt to the cold. Concerning our study, we suggest that particular methanotrophic species faster adapted to the cold than others and that these methanotrophs are presently dominating close to the permafrost table.

The evidence of microbial communities that prefer the cold provided by our study is not consistent with related studies that reveal that microorganisms can survive the extreme conditions of permafrost soils but do not prefer this environment (Rothschild and Mancinelli, 2001). The prerequisite for bacteria to become 'cold loving' specialists are constantly low in situ temperatures over a long period of time (Morita, 1995). However, the temporal dimensions required to become cold adapted or even cold specialized remain to be defined. In deep zones of the active layer close to the permanently frozen ground, temperatures have constantly been below $2^{\circ} \mathrm{C}$ for several hundreds of years. Our study indicates that this time was sufficient for some methanotrophs to become psychrophiles. However, based on our results we cannot state whether the process of cold adaptation was coupled to speciation.

In the upper and younger part of the active layer, the temperatures fluctuate at greater amplitude. Frozen throughout the rest of the year, they reach up to $18^{\circ} \mathrm{C}$ during the summer period. Thus, the process of specialization to extremely low temperatures is seasonally disturbed in the near surface horizon.

Independently of the temperature we detected significantly lower cell activities of methanotrophs near the surface compared with methanotrophs near the permafrost table. Given the steep vertical gradient of the methane concentrations, this might be an indication for substrate-limiting conditions in incubations of near surface samples. We detected in situ methane concentrations that exceeded the atmospheric methane concentration ( $2.5 \mathrm{nM})$ by at least 20 times throughout all the active layer profiles. This indicates methane production in the soil. However, the in situ methane concentrations in this study are rather low compared with other wetlands (Hanson and Hanson, 1996) or rice field soils (Henckel et al., 2000; Macalady et al., 2002) and would support high-affinity methanotrophs. Substrate-limiting conditions in incubations of near surface samples would also explain why horizons with the highest abundance of methanotrophs did not show any temperature dependence of their methane oxidation potential. Davidson and colleagues (2006) found that substrate limitations could obliterate possible temperature optima. In their study they could show that reduced substrate availability caused a decrease in temperature sensitivity of microbial decomposition processes. We have to keep in mind, though, that the in situ methane concentrations measured in this study reflect an excess of methane in the pore volumes but do not reflect in situ methane fluxes. Apart from possible substrate-limiting conditions during the incubations, the probes applied in our study could have also missed unknown methanotrophic bacteria near the permafrost table that if detected would reduce the differences between the cell activities near the surface and near the permafrost table. Significant amounts of undetectable cells using oligonucleotide probes were also found by Kobabe and colleagues (2004) investigating the bacterial diversity within a polygon centre on Samoylov Island. They showed that up to $65 \%$ of bacterial cells detected by universal bacterial probes remained unclassified using more specific probes targeting the main groups of soil bacteria.

The distribution of type I and type II methanotrophs and the in situ temperatures in the soils of the polygon rim and the flood plain did not show a significant correlation indicating that the phylogenetic and metabolic divergence between both groups, type I and type II, does not affect the potential to adapt to constantly cold conditions. This is supported by phylogenetic analysis investigating the relationship of psychrophilic and psychrotrophic methanotrophs to other methanotrophs (Trotsenko and Khmelenina, 2005). Psychrophilic and psychrotrophic methanotrophs were found among $\alpha$ - as well as $\gamma$-Proteobacteria.

We found a significant correlation between the distribution of type I and type II methanotrophs and the in situ methane concentration. The correlation could be due to the different metabolic pathways (RuMP versus Serine pathway) utilized by type I and type II methanotrophs with 
a more efficient carbon assimilation of type I methanotrophs (Hanson and Hanson, 1996). Several studies investigated differences in substrate affinities of type I and type II methanotrophs but so far the results do not consistently show one or the other group to clearly prefer either highor low-substrate concentrations. According to studies on rice field soils, type I methanotrophs seem to out-compete type II at very low in situ methane concentrations (Henckel et al., 2000) and type II methanotrophs are strongly related to soil porewater methane concentrations (Macalady et al., 2002), which indicates a higher substrate affinity of type I compared with type II methanotrophs. Other studies (Horz et al., 2002; Knief and Dunfield, 2005; Knief et al., 2006) show members of the type II group as the most oligotrophic methanotrophs. They suggest that type II methanotrophs might be responsible for atmospheric methane consumption. According to our results based on methane concentrations higher than atmospheric but lower than in high-affinity environments, type I methanotrophs dominate in particular in the upper active layer. A dominance of type I methanotrophs in active layers of Siberian permafrost soils from the Lena Delta was already suggested by Wagner and colleagues (2005) who used marker fatty acid analysis to distinguish between type I and type II methanotrophs.

Differences between the methanotrophic communities could not only be shown with respect to active layer depth but also with respect to different geomorphic units. Polygon rim and flood plain seem to provide favourable conditions for methane oxidizing bacteria. Cell counts between $10^{7}$ and $10^{8}$ per gram dry soil even exceed cell counts of methanotrophs in temperate soils located in Europe by at least one order of magnitude (Horz et al., 2002; Eller et al., 2004). We have to consider, though, that cell counts in these studies were obtained by the most probable number and not by direct cell counting. The highest activity of methanotrophs in the flood plain soil compared with the other two sites studied could result from its high proportion of silt and clay material. The surface area and the amount of negative charges determine the sorptive activity for microorganisms and nutrients (Stotzky, 1966; Heijnen et al., 1992). Hence, clay and silt support availability and uptake of substrates.

Significant cell numbers of methanotrophs were detected in deep soil layers that are, according to Fiedler and colleagues (2004), exposed to reduced in situ conditions. This is consistent with methane oxidation potentials observed under in situ conditions near the permanently frozen ground of a polygon rim also located on Samoylov Island (Wagner et al., 2005). Methane oxidation can occur under microaerophilic (Bodegom et al., 2001) and oxygen-limiting conditions (Roslev and King, 1996). Besides, root exoderms can provide oxygen in deep active layer zones and can therefore prevent methano- trophs from oxygen deprivation. Hence, methanotrophs in deep and reduced soil layers should be equally accounted for in models on methane fluxes.

In contrast to polygon rim and flood plain soil, potential oxidation rates and cell counts indicate unfavourable conditions for the methanotrophic community within the polygon centre despite significantly higher methane concentrations. A hampered process of methane oxidation in the polygon centres is in accordance with significantly higher methane emission rates from the centre of ice-wedge polygons compared with the rim (Wagner et al., 2003; Kutzbach et al., 2004). The unfavourable conditions for methanotrophs in the polygon centre may result from constant water saturation supplemented by a lack of oxygen input.

\section{Conclusions and prospects}

We could show that abundance, distribution and ecophysiology of methane oxidizing bacteria in permafrost affected soils from the Lena Delta are determined by microrelief as well as environmental gradients within the active layer. Because the microbial methane oxidation is an essential part of models on methane emissions from wetlands (Walter and Heimann, 2000), these models should consider small-scale variations within the methanotrophic community as observed in our study. However, until now, methane oxidation rates in these models are based on general parameters like Michaelis-Menten kinetics $(\mathrm{Km})$ and $\mathrm{Q}_{10}$-values but differences in substrate affinities and enzyme kinetics of methanotrophs as well as spatial fluctuations of their cell numbers are not considered. Although our study gives a first insight into the importance of these small-scale variations within the active layer, further studies are needed to supply reliable input data for modelling of methane fluxes.

In addition to abundance and distribution, changes within the methanotrophic community composition need to be studied. Cavigelli and Robertson (2001) suggested influences of the change of the microbial community composition on the function of a terrestrial ecosystem in the context of denitrification. It is likely that shifts within the methane oxidizing community composition will affect its function as a sink for methane as the group of methane oxidizers forms the physiologically 'narrowest' group of all trace gas processors. This allows for a clear demonstration of ecosystem-level influences (Schimel and Gulledge, 1998).

Finally, we should aim at understanding the stability of the methanotrophic community in soils from the Lena Delta in the context of global change. For this purpose it is necessary to extend the usage of molecular tools and to combine our data with an analysis of the diversity of the seasonally active methanotrophic 'keyplayers'. 


\section{Experimental procedure}

\section{Study site and soil properties}

With an area of about $32000 \mathrm{~km}^{2}$ the Lena Delta is the second largest delta in the world (Are and Reimnitz, 2000). It is located in the zone of continuous permafrost and characterized by arctic continental climate with a mean annual air temperature of $-11.9^{\circ} \mathrm{C}$ over the $2001-2003$ period and a mean precipitation during the same period of about $233 \mathrm{~mm}$ (measured by the Russian weather station Stolb Island). Our study site is located in the youngest and presently most active part of the delta on Samoylov Island $\left(\mathrm{N} 72^{\circ} 22\right.$, E $\left.126^{\circ} 28\right)$. Detailed descriptions of the geomorphology of Samoylov Island and the whole delta were given previously by Schwamborn and colleagues (2002). Samoylov Island covers an area of only 1200 ha with the highest elevation at $12 \mathrm{~m}$ above sea level. The island is dominated by the typical permafrost pattern of lowcentred ice-wedge polygons covering at least $70 \%$ of the island area. The soils in the Lena Delta are entirely frozen for at least 8 months every year leaving only a shallow active layer of about $20-50 \mathrm{~cm}$ unfrozen during the summer months.

Expeditions to Samoylov Island were carried out in summers 2002 and 2005 in the frame of the Russian-German cooperation 'System Laptev Sea 2000'. Samoylov was defined with respect to different characteristic geomorphic units. Exemplarily, a polygon rim, a polygon centre and a flood plain soil were chosen for sampling. We defined our sampling sites according to soil horizons following Schoeneberger and colleagues (2002). These soil horizons are characterized according to soil genesis, physical and chemical parameters. Given that bacteria are associated with mineral and organic soil particles (Christensen et al., 1999), it is reasonable to assign microbial communities to soil horizons. It is noteworthy that cryoturbation, a common phenomenon in permafrost affected soils hampering a static view on active layer profiles, is negligible through all our studied profiles.

The two profiles at the rim and at the centre of a lowcentred polygon were located in the eastern part of the island. The distance between these two profiles was approximately $7 \mathrm{~m}$ and the difference in elevation between the rim and the depressed centre was approximately $0.4 \mathrm{~m}$. At the time of sampling (July 2005) the standing water level was in a depth of approximately $38 \mathrm{~cm}$ at the rim and at approximately $10 \mathrm{~cm}$ above the surface of the polygon centre. The permafrost table was in a depth of $38 \mathrm{~cm}$ at the polygon rim and in a depth of $30 \mathrm{~cm}$ at the polygon centre. The third profile was located on a flood plain in the northern part of the island. At this location, annual flooding leads to a continuing accumulation of fluvial sediments. At the time of sampling (July 2002) the permafrost table was in a depth of $54 \mathrm{~cm}$. Soil samples were taken horizontally stepwise, stored in Nalgene boxes, frozen immediately after sampling and transported to Germany for further processing. In situ methane concentrations and temperatures were determined in the field according to Wagner and colleagues (2005). Additional soil characteristics (grain size fraction, content of organic carbon, nitrogen and water) were analysed according to Schlichting and colleagues (1995).

\section{Fixation of cells for hybridization}

Fresh soil samples of each horizon were fixed according to Pernthaler and colleagues (2001). Subsamples (0.5 ml) were fixed with $1.5 \mathrm{ml}$ freshly prepared $4 \%$ paraformaldehyde/ phosphate-buffered saline (PBS) solution ( $\mathrm{pH} 7.2-7.4)$ for $4-5 \mathrm{~h}$ at $4^{\circ} \mathrm{C}$. Fixed samples were diluted with $0.1 \%$ sodium pyrophosphate in distilled water to obtain 100-300 cells (total) per microscopic field of view (63 $\times 100$ objective). The dilution was treated with mild sonication using an MS73 probe (Sonoplus HD70; Bandelin, Berlin, Germany) at a setting of $20 \mathrm{~s}$ to separate cells from soil particles. As a result of the comparatively much higher background fluorescence of soil particles observed after hybridization on membrane filters (own observations) the dispersed soil samples were spotted on gelatine-coated Teflon-laminated slides (Zarda et al., 1997) with 10 wells. Replicates of $10 \mu \mathrm{l}$ of fixed and dispersed soil sample and $2 \mu \mathrm{l}$ of $0.2 \%$ sodium dodecyl sulfate (SDS) were dropped onto each well resulting in full coverage of the well. Slides were dried at $45^{\circ} \mathrm{C}$ for $15 \mathrm{~min}$ and dehydrated in $50 \%, 80 \%$ and $96 \%$ ethanol.

\section{Fluorescence in situ hybridization (FISH) and DAPI staining}

The FISH method was used directly in soil samples because extraction of bacterial cells from soil is difficult to perform due to the exclusion of bacteria associated with soil particles (Christensen et al., 1999).

All oligonucleotide probes used in this study were purchased from Interactiva (Ulm, Germany). They were all labelled with the cyanine dye Cy3. Probes for the domain Bacteria and the families Methylococcaceae (type I methanotrophs) and Methylocystaceae (type II methanotrophs) were used. Probe names, details and references are summarized in Table 3. For in situ hybridization, a $10 \mu$ laliquot of hybridization buffer $(0.9 \mathrm{M} \mathrm{NaCl}, 20 \mathrm{mM}$ Tris- $\mathrm{HCl}$; pH 8.0, 0.02\% SDS), formamide in concentrations according to Table 3 , and $30 \mathrm{ng} \mathrm{Il}^{-1}$ of probe were dropped onto each well. The slides were transferred to an equilibrated $50 \mathrm{ml}$ polypropylene top tube and incubated at $46^{\circ} \mathrm{C}$ for $120 \mathrm{~min}$. Slides were then washed at $48^{\circ} \mathrm{C}$ for $10 \mathrm{~min}$ in washing buffer $(20 \mathrm{mM}$ Tris$\mathrm{HCl}$; $\mathrm{pH}$ 8.0, $5 \mathrm{mM}$ EDTA, 0.01\% SDS w/v and $225 \mathrm{mM} \mathrm{NaCl}$ according to a formamide concentration of $20 \%$ in the hybridization buffer). Afterwards they were washed in ice-cold double distilled water for a few seconds and quickly dried in an air stream. Subsequently, $10 \mu \mathrm{l}$ of $4^{\prime} 6$-Diaminodino-2phenylindole (DAPI, $1 \mu \mathrm{g} \mathrm{ml}^{-1}$ working solution) was dropped onto each well and incubated in the dark at room temperature for 10-15 $\mathrm{min}$. Slides were then washed in ice-cold doubledistilled water and allowed to air-dry. Finally, slides were embedded in Citiflour AF1 antifadent (Plano; Wetzlar, Germany) and covered with a coverslip.

\section{Determination of cell counts}

Microscopy was carried out with a Zeiss Axioskop 2 equipped with filters 02 (DAPI), 10 (FLUOS, DTAF) and 20 (Cy3), a mercury-arc lamp and an AxioCam digital camera. The counting was done manually. For each hybridization approach and 
Table 3. rRNA-targeted oligonucleotide probes used for FISH.

\begin{tabular}{lllll}
\hline Probe & Target group & Target site $^{\mathrm{a}}$ & FA $^{\mathrm{b}}(\%)$ & Reference \\
\hline EUB338 & Domain Bacteria & 16S rRNA (338) & $0-50$ & Amann and colleagues (1990) \\
EUB338 II & Domain Bacteria & 16S rRNA (338) & $0-50$ & Daims and colleagues (1999) \\
EUB338 III & Domain Bacteria & 16S rRNA (338) & $0-50$ & Daims and colleagues (1999) \\
NON338 & Control probe complementary to EUB338 & 16S rRNA & n.d. & Wallner and colleagues (1993) \\
Ma450 & Type II MOB ${ }^{c}$ & 16S rRNA (450) & 20 & Eller and colleagues (2001) \\
Mg705 & Type I MOB ${ }^{c}$ & 16S rRNA (705) & 20 & Eller and colleagues (2001) \\
Mg84 & Type I MOB $^{c}$ & 16S rRNA (84) & 20 & Eller and colleagues (2001) \\
\hline
\end{tabular}

a. Escherichia coli numbering.

b. Percentage $(\mathrm{v} / \mathrm{v})$ of formamide in the hybridization buffer

c. Methane oxidizing bacteria.

n.d., not determined.

sample at least 800 DAPI stained cells were counted on 30 randomly chosen counting squares. Microscopy was carried out using $63 \times 100$ magnification giving an area of $3.9204 \times 10^{-2} \mathrm{~mm}^{2}$ per counting square. Using $\mathrm{FISH}$, only cells with a sufficient number of ribosomes are detected (Amann et al., 1995). The number of these cells was calculated by counting probe-specific positive signals relatively to DAPI counts. Counting results were always corrected by subtracting signals obtained with the probe NON338. Unspecific cell counts were in the range of $3.53 \times 10^{5}-2.7 \times 10^{6}$ cells $\mathrm{g}^{-1}(\mathrm{dw})$. For calculating the number of cells per cubic centimetre of slurry (bacterial counts per volume, $\mathrm{BC}_{\mathrm{v}}$ ), the mean count of bacteria per counting area (B), the microscope factor (area of sample spot/area of counting field, $M$ ), the dilution factor (D) and the volume of the fixed sample used for hybridization (V) were determined and arranged in the equation:

$\mathrm{BC}_{\mathrm{v}}=\mathrm{BM} \mathrm{D} \mathrm{V} \mathrm{M}^{-1}$

Finally, the bacterial counts per millilitre of slurry were converted into cells per gram of soil (dw) according to the equation:

$\mathrm{BC}_{\mathrm{w}}=\mathrm{BC}_{\mathrm{v}}(1+\mathrm{WC} / 100) \mathrm{D}$

where $\mathrm{BC}_{\mathrm{w}}$ are the cells per gram of soil $(\mathrm{dw}), \mathrm{WC}$ is the water content of the slurries and $\mathrm{D}$ is the density of the dried soil.

\section{Potential methane oxidation rates}

The methane oxidation rates of the polygon rim and the polygon centre were determined in incubations without headspace via the conversion of ${ }^{14} \mathrm{CH}_{4}-{ }^{14} \mathrm{CO}_{2}$ modified according to Iversen and Blackburn (1981). Before the tracer experiment, thoroughly homogenized subsamples $(160 \mathrm{~g})$ of each soil horizon were mixed with autoclaved tap water at the ratio of $1: 1(\mathrm{w} / \mathrm{v})$ and incubated in $1 \mathrm{I}$ glass bottles at $4^{\circ} \mathrm{C}$ with $3 \%$ $\mathrm{CH}_{4}$. The slurries were shaken continuously at $120 \mathrm{rpm}$ and $\mathrm{CH}_{4}$ concentrations were determined daily using gas chromatography. Subsequent radiotracer analysis was compared according to incubations with and without headspace. Incubations without headspace: three replicates per slurry and temperature were distributed to $5 \mathrm{ml}$ Hungate tubes and sealed with butyl-rubber stoppers and screw caps leaving no gas bubbles inside the tube. Anaerobically stored ${ }^{14} \mathrm{CH}_{4}$ tracer (Fa. Amersham) was injected. Replicates were incubated at six different temperatures, namely $0,4,12,21,28$ and $38^{\circ} \mathrm{C}$, for $13 \mathrm{~h}$ at methane concentrations between 50 and $1200 \mathrm{nmol} \mathrm{g}^{-1}(\mathrm{dw})$ according to the methane concentrations determined in situ. Incubations with headspace: three replicates per slurry were distributed to $16 \mathrm{ml}$ Hungate tubes leaving $3 \mathrm{ml}$ of headspace and ${ }^{14} \mathrm{CH}_{4}$ tracer was injected. Replicates were incubated for $72 \mathrm{~h}$ to allow sufficient tracer to dissolve into the sample. Near surface samples were incubated at $21^{\circ} \mathrm{C}$ and near permafrost samples were incubated at $4^{\circ} \mathrm{C}$, because previous tests had shown that maximum activities were detected at these temperatures at the according depths. Methane oxidation rates (MOR) were calculated as nanomoles of $\mathrm{CH}_{4}$ oxidized per gram dry weight (dw) and day according to the equation:

$\operatorname{MOR}=\left[\mathrm{CH}_{4}\right] \mathrm{a} /(A t)$

where $\left[\mathrm{CH}_{4}\right]$ is the sediment concentration of methane in $\mathrm{nmol} \mathrm{cm}^{-3}$ dry volume (dv), a are the counts recovered as ${ }^{14} \mathrm{CO}_{2}, A$ are the counts recovered as (remaining) ${ }^{14} \mathrm{CH}_{4}$ and $t$ is the incubation time (days). Rates are based on three replicates and were corrected according to five blanks for each temperature running the same analysis. The potential methane oxidation rates in incubations without headspace were comparable to those in incubations with headspace (data not shown) so that we could exclude possible oxygen deficits limiting the process of methane oxidation in incubations without headspace.

The potential methane oxidation of the flood plain profile was determined by gas chromatography with the aid of difluoromethane $\left(\mathrm{CH}_{2} \mathrm{~F}_{2}\right)$ inhibiting the process of methane oxidation (Krueger et al., 2002). Thoroughly homogenized subsamples (30 g per horizon) were divided into three replicates, filled into sterile serum bottles $(120 \mathrm{ml})$, mixed with autoclaved tap water at the ratio of $1: 1(\mathrm{w} / \mathrm{w})$ and vortexed for $20 \mathrm{~s}$. The slurries were incubated over night at 0, 4, 12 and $21^{\circ} \mathrm{C}$. The supernatant was decanted and the bottles were closed with a screw cap containing a septum. Subsequently, methane concentrations between 50 and $200 \mathrm{nmol} \mathrm{g}^{-1}(\mathrm{dw})$ were adjusted according to the methane concentrations determined in situ and the samples were again incubated at the accordant temperature. The methane concentration in the headspace was determined twice per day for a period of 6 days. Afterwards, the bottles were evacuated and again incubated as described but additionally with $\mathrm{CH}_{2} \mathrm{~F}_{2}$ (8000 ppm). Gas analysis was carried out as described below. Potential methane oxidation rates were calculated from the linear regression of methane concentrations in the 
headspace taking into account methane production rates in samples incubated with $\mathrm{CH}_{2} \mathrm{~F}_{2}$.

$\mathrm{MOR}=-\mathrm{MOR}_{\text {with_inhibitor }}+\mathrm{MOR}_{\text {without_inhibitor }}$

\section{Gas analysis}

Gas analysis was carried out with a gas chromatograph (Agilent 6890, Fa. Agilent Technologies) equipped with a Carbonplot capillary column ( $\varnothing 0.53 \mathrm{~mm}, 30 \mathrm{~m}$ length) and a flame ionization detector (FID). Oven as well as injector temperature was $45^{\circ} \mathrm{C}$. The temperature of the detector was $250^{\circ} \mathrm{C}$. Helium served as carrier gas.

\section{Acknowledgements}

The authors acknowledge T. Treude and I. Müller (Max Planck Institute for Marine Microbiology) for introducing us into the radiotracer experiment as well as J. Harder (Max Planck Institute for Marine Microbiology) for helpful discussions and H. Lantuit, T. Sachs and C. Wille (Alfred Wegener Institute for Polar and Marine Research) for critical reading of the manuscript. Also, we want to thank the crew of the Expedition LENA 2005, in particular Waldemar Schneider for logistic and Günter 'Molo' Stoof for technical support (both Alfred Wegener Institute for Polar and Marine Research). Finally, we thank all our Russian partners, in particular Dimitry Yu. Bolshiyanov (Arctic Antarctic Research Institute), Alexander Yu. Dereviagin (Moscow State University), Mikhail N. Grigoriev (Permafrost Institute Yakutsk), Dmitri V. Melnitschenko (Hydro Base Tiksi) and Alexander Yu. Gukov (Lena Delta Reserve).

\section{References}

Amann, R., Binder, B.J., Olson, R.J., Chisholm, S.W., Devereux, R., and Stahl, D.A. (1990) Combination of $16 S$ rRNA-targeted oligonucleotide probes with flow cytometry for analyzing mixed microbial populations. Appl Environ Microbiol 56: 1919-1925.

Amann, R., Ludwig, W., and Schleifer, K.H. (1995) Phylogenetic identification and in situ detection of individual microbial cells without cultivation. FEMS Microbiol Rev 59: 143169.

Anisimov, O.A., Nelson, F.E., and Pavlov, A.V. (1999) Predictive scenarios of permafrost development under conditions of global climate change in the XXI century. Earth Cryology 3: 15-25.

Are, F., and Reimnitz, E. (2000) An overview of the Lena River Delta settings: geology, tectonics, geomorphology, and hydrology. J Coastal Res 16: 1083-1093.

Bodegom, P.V., Stams, F., Mollema, L., Boeke, S., and Leffelaar, P. (2001) Methane oxidation and the competition for oxygen in the rice rhizosphere. Appl Environ Microbiol 67: 3586-3597.

Cao, M., Marshall, S., and Gregson, K. (1996) Global carbon exchange and methane emission from natural wetlands: application of a process-based model. J Geophys Res 101: $14399-14414$.

Cavicchioli, R. (2006) Cold-adapted archaea. Nature 4: 331343.
Cavigelli, M.A., and Robertson, G.P. (2001) Role of denitrifier diversity in rates of nitrous oxide consumption in a terrestrial ecosystem. Soil Biology Biochem 33: 297-310.

Christensen, T.R., Jonasson, S., Havstroem, M., and Livens, F.R. (1999) Carbon cycling and methane exchange in Estuarine tundra ecosystems. AMBIO 28: 239-244.

Corradi, C., Kolle, O., Walter, K., Zimov, S.A., and Schulze, E.D. (2005) Carbon dioxide and methane exchange of a north-east Siberian tussock tundra. Global Change Biology 11: 1-16.

Daims, H., Bruehl, A., Amann, R., Schleifer, K.H., and Wagner, M. (1999) The domain specific probe EUB338 is insufficient for the detection of all Bacteria, development and evaluation of a more comprehensive probe set. Syst Appl Microbiol 22: 434-444.

Davidson, E.A., Janssens, I.A., and Luo, Y. (2006) On the variability of respiration in terrestrial ecosystems: moving beyond Q10. Global Change Biology 12: 154-164.

Eller, G., Stubner, S., and Frenzel, P. (2001) Group-specific 16 rRNA targeted probes for detection of type I and type II methanotrophs by fluorescence in situ hybridisation. FEMS Microbiol Lett 198: 91-97.

Eller, G., Krüger, M., and Frenzel, P. (2004) Comparing field and microcosm experiments: a case study on methanoand methylotrophic bacteria in paddy soil. FEMS Microbiol Ecol 51: 279-291.

Fiedler, S., Wagner, D., Kutzbach, L., and Pfeiffer, E.M. (2004) Element redistribution along hydraulic and Redox gradients of low-centred polygons, Lena Delta, Northern Siberia. Soil Sci Soc Am 68: 1002-1011.

Friborg, T., Soegaard, H., Christensen, T.R., Lloyd, C.R., and Panikov, N. (2003) Siberian wetlands: where a sink is a source. Geophys Res Lett 30: 2129.

Fung, I., John, J., Lerner, J., Matthews, E., Prather, M., Steele, L.P., and Fraser, P.J. (1991) Three-dimensional model synthesis of the global methane cycle. $J$ Geophys Res 96: 13033-13065.

Georlette, D., Blaise, V., Collins, T., D’Amico, S., Gratia, E., Hoyoux, A., et al. (2004) Some like it cold: biocatalysis at low temperatures. FEMS Microbiol Rev 28: 25-42.

Hanson, R.S., and Hanson, T.E. (1996) Methanotrophic bacteria. Microbiol Rev 60: 439-471.

Heijnen, C.E., Hok-A-Hin, C.H., and Van Veen, J.A. (1992) Improvements to the use of bentonite clay as a protective agent increasing survival levels of bacteria introduced into soil. Soil Biology Biochem 24: 533-538.

Henckel, T., Roslev, P., and Conrad, R. (2000) Effects of $\mathrm{O}_{2}$ and $\mathrm{CH}_{4}$ on presence and activity of the indigenous methanotrophic community in rice field soil. Environ Microbiol 2: 666-679.

Horz, H.P., Raghubanshi, A.S., Heyer, J., Kammann, C., Conrad and Dunfield, P.F. (2002) Activity and community structure of methane-oxidising bacteria in a wet meadow soil. FEMS Microbiol Ecol 41: 247-257.

IPCC (2001) Climate Change 2001: The Scientific Basis. Contribution of Working Group I to the Third Assessment Report of the Intergovernmental Panel on Climate Change. Cambridge: Cambridge University Press.

Iversen, N., and Blackburn, H. (1981) Seasonal rates of methane oxidation in anoxic marine sediments. Appl Environ Microbiol 41: 1295-1300. 
Joabsson, A., and Christensen, T.R. (2001) Methane emissions from wetlands and their relationship with vascular plants: an Arctic example. Global Change Biology 7: 919932.

Knief, C., and Dunfield, P.F. (2005) Response and adaptation of different methanotrophic bacteria to low methane mixing ratios. Environ Microbiol 7: 1307-1317.

Knief, C., Kolb, S., Bodelier, P.L.E., Lipski, A., and Dunfield, P.F. (2006) The active methanotrophic community in hydromorphic soils changes in response to changing methane concentration. Environ Microbiol 8: 321-333.

Kobabe, S., Wagner, D., and Pfeiffer, E.M. (2004) Characterisation of microbial community composition of a Siberian tundra soil by fluorescence in situ hybridisation. FEMS Microbiol Ecol 50: 13-23.

Krueger, M., Eller, G., Conrad, R., and Frenzel, P. (2002) Seasonal variation in pathways of $\mathrm{CH}_{4}$ production and in $\mathrm{CH}_{4}$ oxidation in rice fields determined by stable carbon isotopes and specific inhibitors. Global Change Biology 8: 265-280.

Kutzbach, L., Wagner, D., and Pfeiffer, E.M. (2004) Effect of microrelief and vegetation on methane emission from wet polygonal tundra, Lena Delta, Northern Siberia. Biogeochemistry 69: 341-362.

Le Mer, J., and Roger, P. (2001) Production, oxidation, emission and consumption of methane by soils: a review. Eur $J$ Soil Biology 37: 25-50.

Macalady, J.L., McMillan, A.M., Dickens, A.F., Tyler, S.C., and Scow, K.M. (2002) Population dynamics of type I and II methanotrophic bacteria in rice soils. Environ Microbio/ 4: 148-157.

Morita, R.Y. (1995) Low-Temperature Environ-ments. Encyclopedia of Microbiology, Vol. 2. San Diego, CA, USA: Academic Press.

Pernthaler, J., Gloeckner, F.O., Schoenhuber, W., and Amann, R. (2001) Fluorescence in situ hybridization (FISH) with rRNA-targeted oligonucleotide probes. Methods Microbiol: Mar Microbiol 30: 207-226.

Post, W.M., Emanuel, W.R., Zinke, P.J., and Stangenberger, A.G. (1982) Soil carbon pools and world life zones. Nature 298: 156-159.

Roslev, P., and King, G.M. (1996) Regulation of methane oxidation in a freshwater wetland by water table changes and anoxia. FEMS Microbiol Ecol 19: 105-115.

Rothschild, L.J., and Mancinelli, R.L. (2001) Life in extreme environments. Nature 409: 1092-1101.

Schimel, J.P., and Gulledge, J. (1998) Microbial community structure and global trace gases. Global Change Biology 4: 745-758.

Schlichting, E., Blume, H.P., and Stahr, K. (eds). (1995) Bodenkundliches Praktikum: Pareys Studientexte 81. Berlin, Germany: Blackwell Wissensverlag.

Schoeneberger, P.J., Wysocki, D.A., Benham, E.C., and Broderson, W.D. (eds). (2002) Field Book for Describing and Sampling Soils. Lincoln, NE, USA: Natural Resources Conservation Service, National Soil Survey centre.

Schwamborn, G., Rachold, V., and Grigoriev, M.N. (2002) Late quaternary sedimentation history of the Lena Delta. Quatern Int 89: 119-134.

Serreze, M.C., Walsh, J.E., Chapin, F.S., III, Osterkamp, T., Dyurgerov, M., Romanovsky, V., et al. (2000) Observational evidence of recent change in the northern high-latitude environment. Climatic Change 46: 159206.

Smith, L.C., MacDonald, G.M., Velichko, A.A., Beilman, W.D., Borisova, O.K., Frey, K.E., et al. (2004) Siberian peatlands: a net carbon sink and global methane source since the early Holocene. Science 303: 353356.

Stotzky, G. (1966) Influence of clay minerals on microorganisms. III. Effect of particle size, cation exchange capacity and surface area on bacteria. Can J Microbiol 12: 1235-1246.

Trotsenko, Y.A., and Khmelenina, V.N. (2005) Aerobic methanotrophic bacteria of cold ecosystems. FEMS Microbiol Ecol 53: 15-26.

Wagner, D., Kobabe, S., Pfeiffer, E.M., and Hubberten, H.W. (2003) Microbial controls on methane fluxes from a polygonal tundra of the Lena Delta, Siberia. Permafrost Periglac Process 14: 173-185.

Wagner, D., Lipski, A., Embacher, A., and Gattinger, A. (2005) Methane fluxes in extreme permafrost habitats of the Lena Delta: effects of microbial community structure and organic matter quality. Environ Microbiol 7: 15821592.

Wallner, G., Amann, R., and Beisker, W. (1993) Optimizing fluorescent in situ hybridization with rRNA-targeted oligonucleotide probes for flow cytometric identification of microorganisms. Cytometry 14: 136-143.

Walter, B.P., and Heimann, M. (2000) A processed-based, climate-sensitive model to drive methane emissions from natural wetlands: applications to five wetland sites, sensitivity to model parameters, and climate. Global Biochem Cycles 14: 745-765.

Whalen, S.C., and Reeburgh, W.S. (1992) Interannual variations in tundra methane emission: a 4-year time series at fixed sites. Global Biochem Cycles 6: 139-159.

Wuebbles, J., and Hayhoe, K. (2002) Atmospheric methane and global change. Earth-Sci Rev 57: 177-210.

Zarda, B., Hahn, D., Chatzinotas, A., Schoenhuber, W., Neef, A., Amann, R., and Zeyer, J. (1997) Analysis of bacterial community structure in bulk soil by in situ hybridization. Arch Microbiol 168: 185-192.

Zhang, T., Barry, R.G., Knowles, K., Heginbotton, J.A., and Brown, J. (1999) Statistics and characteristics of permafrost and ground-ice distribution in the northern hemisphere. Polar Geogr 23: 132-154. 